\title{
The Growth and Distribution of Carcass Fat in Fattening Steer of Different Breeds
}

\author{
R. Priyanto ${ }^{\mathrm{a}}$ \& E. R. Johnson ${ }^{\mathrm{b}}$ \\ ${ }^{a}$ Department of Animal Production and Technology, Faculty of Animal Science, Bogor Agricultural University \\ Jln. Agatis, Kampus IPB Darmaga, Bogor 16680, Indonesia \\ bSchool of Veterinary Science, The University of Queensland \\ Kenmore, Qld 4069, Australia \\ (Received 28-10-2011; accepted 15-03-2012)
}

\begin{abstract}
ABSTRAK
Studi tentang pertumbuhan dan distribusi lemak karkas dilakukan pada tiga bangsa sapi pedaging kastrasi yang memasuki fase penggemukan. Penelitian melibatkan 23 ekor sapi brahman, 24 ekor hereford dan 22 ekor persilangan brahmanxhereford dengan kisaran bobot hidup 300-600 kg. Model pertumbuhan alometrik Huxley digunakan untuk mengkaji pola pertumbuhan dan distribusi lemak karkas pada potongan daging wholesale. Secara umum, brahman memiliki koefisien pertumbuhan lemak pada potongan-potongan daging wholasale yang nyata lebih tinggi dari hereford dan atau persilangan brahmanxhereford. Sementara, sapi hereford dan persilangan brahmanxhereford memiliki koefisien pertumbuhan lemak yang relatif sama. Perbandingan pada log natural bobot setengah karkas tanpa lemak $75 \mathrm{~kg}(4.313 \mathrm{~kg})$, hereford memiliki bobot lemak pada sebagian besar potongan daging wholesale yang nyata lebih tinggi jika dibandingkan dengan brahman dan persilangan brahmanxhereford. Brahman dan hereford menunjukkan distribusi bobot lemak pada potonganpotongan daging wholesale yang relatif sama pada log natural bobot setengah karkas tanpa lemak 114 kg (4.733 kg). Sapi persilangan memiliki bobot lemak pada sebagian besar potongan daging wholesale yang nyata lebih rendah jika dibandingkan dengan hereford dan brahman.
\end{abstract}

Key words: bangsa sapi, kastrasi, fase penggemukan, pertumbuhan, distribusi lemak

\begin{abstract}
The growth and distribution patterns of carcass fat were investigated in three breeds of beef cattle entering fattening phase. The study involved 23 grass-fed steer Brahman, 24 Hereford and 22 Brahmanx Hereford crosses with a live weight range from $300-600 \mathrm{~kg}$. An allometric Huxley model was used to study the growth and distribution patterns of fat tissue within wholesale cut. In most cases, Brahmans had significantly higher growth coefficients than Herefords and/or BrahmanxHereford crosses while Herefords and BrahmanxHereford crosses had similar growth coefficients in wholesale cuts. At log natural of $75 \mathrm{~kg}$ side muscle+bone weight $(4.313 \mathrm{~kg})$, Herefords had significantly a higher fat weight within wholesale cuts than Brahmans and BrahmanxHereford crosses. Comparison at log natural of $114 \mathrm{~kg}$ side muscle+bone weight $(4.733 \mathrm{~kg})$, whilst Brahmans and Herefords were similar in fat weight distribution, the cross-bred steer had lower fat weights than the other two breed groups in almost all wholesale cuts.
\end{abstract}

Key words: steer, breed, fattening phase, fat growth, distribution

\section{INTRODUCTION}

During the fattening phase, the growth impetus of fat was predominantly high relative to that of muscle and bone (Priyanto et al., 2009). This made the former tissue having an important role in determining compositional changes of a carcass and consequently the yield of beef (Mukai et al., 2004; Vieira et al., 2006). The changes

\footnotetext{
* Corresponding author:

E-mail: rd.priyanto@gmail.com
}

in carcass composition after the onset of fattening phase are largely attributable to the increasing proportion of fat in a carcass. Advancing in carcass fatness would be followed by increasing carcass fat but decreasing carcass muscle percentages due to the much higher growth impetus of carcass fat relative muscle and bone (Priyanto et al., 2009). Consequently, increasing carcass fatness during the fattening phase might have a deleterious effect on the yield percentage of saleable beef. It was reported that cattle with larger frame size had better yield percentages of saleable beef, if compared to that with smaller frame size (Bidner et al., 2009). The variation in 
beef yield were associated primarily with maturity type differences because of the differential growth patterns of their carcass tissues (Priyanto et al., 2009).

Fat-free carcass weight was as an effective adjustment factor in breed comparison for muscularity and muscle to bone ratio (Purchas et al., 2002). Previous finding showed significant but small between breed differences in the muscle growth and distribution relative to fat-free carcass weight (Priyanto \& Johnson, 2011). In this study, the influence of beef cattle breed on carcass fat and its distribution throughout the wholesale cuts relative to fatfree carcass weight was examined in fattening steer.

\section{MATERIALS AND METHODS}

The cattle used in the study included 69 grass-fed steers, consisted of 23 Brahmans, 24 Herefords, and 22 BrahmanxHereford Crosses which had enter, or were progressing along, their fat deposition phase. The steers were sequentially slaughtered at approximately 300, 400, 500, and $600 \mathrm{~kg}$ live-weight. All steers were fasted but access to water for $24 \mathrm{~h}$ prior to slaughter. Following dressing, the carcasses were divided into two sides, weighed and then chilled at $3{ }^{\circ} \mathrm{C}$ for $24 \mathrm{~h}$. The right sides were broken down into 15 wholesale cuts, namely Thin flank, Loin, Tenderloin, Rump, Thick Flank, Topside, Silverside, Shank, Point End (PE) Brisket, Navel End (NE) Brisket, Shin, Blade, Rib Set, Chuck, Neck+Sticking (AUSMEAT, 2003). The cuts were then dissected into muscle, fat, bone, and connective tissue. The weights of the carcasses, the hot and chilled sides, wholesale cuts were recorded. All dissection products, including muscle, fat, bone and connective tissue from each cut were weighed and recorded. The dissection of the carcass components were based on recovered weights of the right side.

\section{Statistical Analysis}

An allometric model, $\mathrm{Y}=\alpha \mathrm{X}^{\beta}$ (Huxley, 1932), was used to study the growth patterns of the muscle tissue. In order to obtain a linear relationship, the equation was transformed into log natural form. Breed effects on the relationship between the weight of muscle in the wholesale cut and the weight of side muscle+bone were examined using the following model:

$\operatorname{LnY}_{\mathrm{ij}}=\operatorname{Ln} \alpha+\operatorname{Brd}_{\mathrm{i}}+\beta \operatorname{Ln} X_{\mathrm{ij}}+\beta\left(\mathrm{Brd}_{\mathrm{i}} \operatorname{LnX}_{\mathrm{ij}}+\mathrm{E}_{\mathrm{ij}}\right.$

\section{Where}

$Y_{i j} \quad=$ fat weight in wholesale cut of the $j$ th animal from the $i$ th breed

$\alpha \quad=$ intercept

$B r d$. fixed effect of the $i$ th breed

$X_{i j} \quad=$ side muscle+bone weight of the $j$ th animal from the $i$ th breed

$\beta \quad=$ regression coefficient of $\mathrm{Y}_{\mathrm{ij}}$ on $\mathrm{X}_{\mathrm{ij}}$

$\beta(B r d)_{i}=$ regression coefficient of the $i$ th breed

$E_{i j} \quad=$ residual error of the measurement of $\mathrm{Y}_{\mathrm{ij}}{ }^{\prime}$ assumed to be normally distributed around a mean of zero with a variance of $\sigma^{2}$

This analysis allowed comparisons of breed regression coefficients as suggested by Kaps \& Lamberson (2004), and estimates of dependent variables (Y's) at a particular independent variable $(X)$. In order to obtain more accurate results, the dependent variables were estimated using breed regressions at a particular $X$ value and compared between breeds.

The carcass weight range covered both traditional (light-weight) and specific (heavy-weight) markets, thus it was of particular interest to compare the $\mathrm{Y}$ values at two different values of the independent variable $(X)$, one where the carcasses suitable for the traditional market and one where they were suitable for the specific (hotel, restaurant and institution) market. The traditional market prefer carcasses averaging $200 \mathrm{~kg}$ which correspond to $75 \mathrm{~kg}$ of side muscle+bone weight, while the specific market prefers carcasses averaging $300 \mathrm{~kg}$ or $114 \mathrm{~kg}$ side muscle+bone weight.

\section{RESULTS AND DISCUSSION}

Unlike the growth of muscle within wholesale cuts (Priyanto \& Johnson, 2011), the growth of fat showed more widespread breed variations, 11 of the 15 wholesale cuts differing significantly among breed groups (Table 1). In most cases, Brahmans had significantly higher growth coefficients than Herefords and/or BrahmanxHereford crosses while Herefords and BrahmanxHereford crosses had similar growth coefficients in wholesale cuts. The differential fat growth patterns which were clearly demonstrated among breeds led to some important implications for fat weight distribution when breeds were compared at two growth stages. Comparison of fat weight within wholesale cuts at $\log$ natural of $75 \mathrm{~kg}$ side muscle+bone weight $(4.313 \mathrm{~kg})$ showed that Herefords had consistently and significantly a higher fat content than Brahmans and BrahmanxHereford crosses (Table 2). This occurred in all wholesale cuts except topside, silverside and PE brisket. Brahmans and BrahmanxHereford crosses tended to have a similar fat weight distribution. The differences became more obvious when breeds were compared at the heavier fat-free carcass weight. At log natural of $114 \mathrm{~kg}$ side muscle+bone weight $(4.733 \mathrm{~kg})$, Brahmans and Herefords were similar in the weight estimates of fat in most wolesale cuts due mainly to the relatively higher rate of fat deposition in the Brahmans (Table 3). BrahmanxHereford crosses had a lower total fat weight than the other two breed groups in almost all wholesale cuts, attributable to their generally low fat growth coefficient.

Belk et al. (1991) reported minor influence of breed on the growth and distribution of fat tissue when fat in the wholesale cuts was related to the total carcass fat. This suggests diminished effect of breed on fat growth and distribution when comparisons were made at equal fatness bases. Whilst such studies could provide useful information about patterns of fat growth and distribution, the genetic variation in fattening patterns could not be clearly identified by this approach. Priyanto \& Johnson (2011) reported breed variation in muscle weight distribution whitin wholesale cuts when adjusted to the same carcass weight. The present study confirmed the previous findings that there were significant between breed differences in the growth and 
Table 1. Allometric relationship between fat weight of the wholesale cut $(Y)$ and side muscle+bone weight $(X)$, $\operatorname{Ln} Y=\operatorname{Ln} a+b \operatorname{Ln} X$

\begin{tabular}{|c|c|c|c|c|}
\hline \multirow{3}{*}{ Wholesale cut } & \multicolumn{3}{|c|}{ Growth coefficient $(b) \dagger$} & \multirow{3}{*}{$\mathrm{R}^{2}$} \\
\hline & Hereford & Brahman & BrahmanxHereford & \\
\hline & $\mathrm{b} \pm \mathrm{SE}$ & $\mathrm{b} \pm \mathrm{SE}$ & $\mathrm{b} \pm \mathrm{SE}$ & \\
\hline Thin flank & $2.326 \pm 0.259$ & $2.928 \pm 0.271$ & $2.270 \pm 0.274$ & 0.81 \\
\hline Loin & $2.130 \pm 0.256^{\mathrm{a}}$ & $3.086 \pm 0.268^{b}$ & $2.225 \pm 0.272^{\mathrm{a}}$ & 0.82 \\
\hline Tender loin & $1.426 \pm 0.208^{\mathrm{ab}}$ & $1.737 \pm 0.217^{\mathrm{b}}$ & $0.973 \pm 0.220^{\mathrm{a}}$ & 0.70 \\
\hline Rump & $2.035 \pm 0.226^{a}$ & $2.921 \pm 0.226^{b}$ & $2.092 \pm 0.229^{\mathrm{a}}$ & 0.85 \\
\hline Thick flank & $1.588 \pm 0.170^{\mathrm{b}}$ & $1.608 \pm 0.178^{\mathrm{b}}$ & $1.028 \pm 0.180^{\mathrm{a}}$ & 0.77 \\
\hline Topside & $1.743 \pm 0.211$ & $2.190 \pm 0.220$ & $1.745 \pm 0.223$ & 0.79 \\
\hline Silverside & $2.106 \pm 0.269^{\mathrm{ab}}$ & $2.961 \pm 0.281^{\mathrm{b}}$ & $2.257 \pm 0.285^{\mathrm{a}}$ & 0.85 \\
\hline Shank & $1.078 \pm 0.144$ & $1.392 \pm 0.150$ & $1.030 \pm 0.152$ & 0.77 \\
\hline PE brisket & $1.706 \pm 0.188^{a}$ & $2.296 \pm 0.196^{b}$ & $1.574 \pm 0.199^{\mathrm{a}}$ & 0.82 \\
\hline NE brisket & $2.210 \pm 0.224$ & $2.557 \pm 0.235$ & $1.937 \pm 0.238$ & 0.82 \\
\hline Shin & $1.261 \pm 0.198^{\mathrm{ab}}$ & $1.620 \pm 0.207^{b}$ & $1.039 \pm 0.210^{\mathrm{a}}$ & 0.67 \\
\hline Blade & $1.769 \pm 0.201^{\mathrm{ab}}$ & $2.243 \pm 0.211^{\mathrm{b}}$ & $1.583 \pm 0.213^{\mathrm{a}}$ & 0.80 \\
\hline Rib set & $1.984 \pm 0.196^{a}$ & $2.657 \pm 0.205^{\mathrm{b}}$ & $1.735 \pm 0.208^{\mathrm{a}}$ & 0.85 \\
\hline Chuck & $1.734 \pm 0.160^{\mathrm{ab}}$ & $1.886 \pm 0.168^{b}$ & $1.413 \pm 0.170^{\mathrm{a}}$ & 0.84 \\
\hline Neck+Sticking & $1.720 \pm 0.191^{\mathrm{ab}}$ & $2.123 \pm 0.200^{\mathrm{b}}$ & $1.470 \pm 0.203^{\mathrm{a}}$ & 0.80 \\
\hline
\end{tabular}

Note: $\uparrow$ All breed regression coefficients highly significant $(\mathrm{P}<0.01)$.

Means in the same row with different superscript differ significantly $(\mathrm{P}<0.05)$; the weights of fat within wholesale cut and side muscle+bone were measured in $\mathrm{kg}$.

Table 2. Log natural estimate of fat weight within wholesale cut $(Y)$ at a 4.313 of $\ln$ side muscle+bone weight (X) using breed regression equation; Ln $Y=\operatorname{Ln} a+b \operatorname{Ln} X$

\begin{tabular}{lccc}
\hline Wholesale cut & \multicolumn{2}{c}{ Fat estimate (in ln value) } \\
\cline { 2 - 4 } & Hereford & Brahman & BrahmanxHereford \\
\hline Thin flank & $0.149 \pm 0.078^{\mathrm{b}}$ & $-0.034 \pm 0.089^{\mathrm{a}}$ & $-0.132 \pm 0.091^{\mathrm{ab}}$ \\
Loin & $0.624 \pm 0.077^{\mathrm{b}}$ & $0.245 \pm 0.088^{\mathrm{a}}$ & $0.134 \pm 0.090^{\mathrm{a}}$ \\
Tender loin & $-0.872 \pm 0.062^{\mathrm{b}}$ & $-1.090 \pm 0.071^{\mathrm{a}}$ & $-1.163 \pm 0.073^{\mathrm{a}}$ \\
Rump & $0.289 \pm 0.065^{\mathrm{b}}$ & $-0.043 \pm 0.074^{\mathrm{a}}$ & $-0.030 \pm 0.076^{\mathrm{a}}$ \\
Thick flank & $-0.239 \pm 0.051^{\mathrm{b}}$ & $-0.436 \pm 0.058^{\mathrm{a}}$ & $-0.311 \pm 0.060^{\mathrm{ab}}$ \\
Topside & $0.300 \pm 0.063$ & $0.191 \pm 0.072$ & $0.141 \pm 0.074$ \\
Silverside & $-0.147 \pm 0.060$ & $-0.212 \pm 0.068$ & $-0.194 \pm 0.070$ \\
Shank & $-0.219 \pm 0.043^{\mathrm{c}}$ & $-0.588 \pm 0.049^{\mathrm{a}}$ & $-0.422 \pm 0.050^{\mathrm{b}}$ \\
PE brisket & $0.489 \pm 0.056$ & $0.339 \pm 0.064$ & $0.370 \pm 0.066$ \\
NE brisket & $0.304 \pm 0.067^{\mathrm{b}}$ & $0.051 \pm 0.077^{\mathrm{a}}$ & $0.043 \pm 0.079^{\mathrm{a}}$ \\
Shin & $-0.631 \pm 0.059^{\mathrm{b}}$ & $-0.849 \pm 0.068^{\mathrm{a}}$ & $-0.762 \pm 0.069^{\mathrm{ab}}$ \\
Blade & $0.419 \pm 0.060^{\mathrm{b}}$ & $0.035 \pm 0.069^{\mathrm{a}}$ & $0.133 \pm 0.071^{\mathrm{a}}$ \\
Rib set & $0.101 \pm 0.059^{\mathrm{b}}$ & $-0.145 \pm 0.067^{\mathrm{a}}$ & $-0.289 \pm 0.069^{\mathrm{a}}$ \\
Chuck & $0.309 \pm 0.048^{\mathrm{b}}$ & $0.051 \pm 0.055^{\mathrm{a}}$ & $0.103 \pm 0.056^{\mathrm{a}}$ \\
Neck+Sticking & $0.221 \pm 0.057^{\mathrm{b}}$ & $-0.110 \pm 0.066^{\mathrm{a}}$ & $-0.026 \pm 0.067^{\mathrm{a}}$
\end{tabular}

Note: The weights of fat within wholesale cut and side muscle+bone were measured in kg; Means in the same row with different superscript differ significantly $(\mathrm{P}<0.05)$.

distribution of carcass fat whitin wholesale cuts relative to fat-free carcass weight.

There were important breed variations in both fat growth and weight distribution, which followed a sys- tematic pattern. In lightweight carcasses, Hereford steers deposited more fat in the wholesale cuts than Brahmans and BrahmanxHereford steers. Because fat deposition was relatively faster in Brahmans once they entered the 
Table 3. Log natural estimate of fat weight within wholesale cut $(\mathrm{Y})$ at a 4.733 of $\ln$ side muscle+bone weight $(\mathrm{X})$ using breed regression equation; $\operatorname{Ln} Y=\operatorname{Ln} a+b \operatorname{Ln} X$

\begin{tabular}{|c|c|c|c|}
\hline \multirow{2}{*}{ Wholesale cut } & \multicolumn{3}{|c|}{ Fat estimate (in ln value) } \\
\hline & Hereford & Brahman & BrahmanxHereford \\
\hline Thin flank & $1.124 \pm 0.096^{\mathrm{b}}$ & $1.193 \pm 0.089^{b}$ & $0.820 \pm 0.090^{a}$ \\
\hline Loin & $1.517 \pm 0.095^{\mathrm{b}}$ & $1.549 \pm 0.088^{\mathrm{b}}$ & $1.067 \pm 0.089^{a}$ \\
\hline Tender loin & $-0.274 \pm 0.077^{\mathrm{b}}$ & $-0.362 \pm 0.071^{\mathrm{b}}$ & $-0.755 \pm 0.072^{a}$ \\
\hline Rump & $1.142 \pm 0.080^{\mathrm{b}}$ & $1.181 \pm 0.074^{\mathrm{b}}$ & $0.847 \pm 0.075^{\mathrm{a}}$ \\
\hline Thick flank & $0.426 \pm 0.063^{b}$ & $0.238 \pm 0.058^{\mathrm{a}}$ & $0.120 \pm 0.059^{a}$ \\
\hline Topside & $1.026 \pm 0.078^{\mathrm{b}}$ & $1.109 \pm 0.072^{\mathrm{ab}}$ & $0.873 \pm 0.073^{\mathrm{a}}$ \\
\hline Silverside & $0.736 \pm 0.074^{\mathrm{ab}}$ & $0.883 \pm 0.068^{\mathrm{b}}$ & $0.592 \pm 0.069^{\mathrm{a}}$ \\
\hline Shank & $0.233 \pm 0.053^{\mathrm{b}}$ & $-0.005 \pm 0.049^{\mathrm{a}}$ & $0.010 \pm 0.050^{\mathrm{a}}$ \\
\hline PE brisket & $1.204 \pm 0.070^{\mathrm{ab}}$ & $1.302 \pm 0.064^{\mathrm{b}}$ & $1.030 \pm 0.065^{\mathrm{a}}$ \\
\hline NE brisket & $1.231 \pm 0.083^{\mathrm{b}}$ & $1.123 \pm 0.077^{\mathrm{b}}$ & $0.855 \pm 0.078^{a}$ \\
\hline Shin & $-0.103 \pm 0.074^{\mathrm{b}}$ & $-0.170 \pm 0.068^{\mathrm{a}}$ & $-0.327 \pm 0.069^{\mathrm{ab}}$ \\
\hline Blade & $1.161 \pm 0.075^{\mathrm{b}}$ & $0.976 \pm 0.069^{\mathrm{ab}}$ & $0.797 \pm 0.070^{\mathrm{a}}$ \\
\hline Rib Set & $0.933 \pm 0.073^{\mathrm{b}}$ & $0.969 \pm 0.067^{\mathrm{b}}$ & $0.438 \pm 0.068^{\mathrm{a}}$ \\
\hline Chuck & $1.036 \pm 0.060^{\mathrm{b}}$ & $0.841 \pm 0.055^{\mathrm{a}}$ & $0.696 \pm 0.056^{\mathrm{a}}$ \\
\hline Neck+Sticking & $0.945 \pm 0.071^{\mathrm{b}}$ & $0.780 \pm 0.066^{\mathrm{b}}$ & $0.590 \pm 0.067^{\mathrm{a}}$ \\
\hline
\end{tabular}

Note: The weights of fat within wholesale cut and side muscle+bone were measured in $\mathrm{kg}$; Means in the same row with different superscript differ significantly $(\mathrm{P}<0.05)$.

fattening phase, the fat weight distribution between Herefords and Brahmans was similar in heavyweight carcasses. BrahmanxHereford crosses showed the slowest development for fat and consequently had less fat weight particularly in the proximal fore-limb and lumbar regions when compared with the other two breeds. It was suggested that maturity type of cattle breed differences in the fattening pattern might be explained in terms of the onset of fattening and/or the rate of fattening (Bidner et al., 2002; Gotoh et al., 2009), and these were reflected in fat-free carcass weight differences among breed at which the fattening phase commenced.

\section{CONCLUSION}

In fattening steer, there were significant between breed differences in fat growth and distribution whitin wholesale cuts. At the lower side muscle+bone weight, Hereford generally had more fat within wholesale cuts relative to Brahman and BrahmanxHereford cross. At the heavier side muscle+bone weight, however, Brahman and Hereford had similar fat weight distribution in the carcass, indicating a faster growth of fat from Brahman steer.

\section{REFERENCES}

AUS-MEAT. 2003. Technical Manual of Australian Meat. Australian Meat and Livestock Corporation, Sydney.

Belk, K. E., J. D. Tatum, \& Jr. F. L. Williams. 1991. Deposition and distribution of carcass fat for steers differing in frame size and muscle thickness. J. Anim. Sci. 69: 609-616.
Bidner, T. D., W. E. Wyatt, P. E. Humes, D. E. Franke, \& D. C. Blouin. 2002. Influence of Brahman-derivative breeds and Angus on carcass traits, physical composition, and palatability. J. Anim Sci. 80:2126-2133.

Bidner, T. D., P. E. Humes, W. E. Wyatt, D. E. Franke, M. A. Persica, G. T. Gentry, \& D. C. Blouin. 2009. Influence of Angus and Belgian Blue bulls mated to Hereford $x$ Brahman cows on growth, carcass traits, and longissimus steak shear force. J. Anim Sci. 87:1167-1173.

Gotoh, T., E. Albrecht, F. Teuscher, K. Kawabata, K. Sakashita, H. Iwamoto, \& J. Wegner. 2009. Differences in muscle and fat accretion in Japanese Black and European cattle. Meat Sci. 82: 300-3008.

Huxley, J. S. 1932. Problems of Relative Growth. Methuen, London.

Kaps, M. \& W. R. Lamberson. 2004. Biostatistics for Animal Science. CABI Publishing. Oxfordshire.

Mukai, F., M. Sadahira, \& T. Yoshimura. 2004. Comparison of carcass composition among Japanese Black, Holstein and their crossbred steers fattening on farm. Anim. Sci. J. 75: 393-399.

Priyanto, R., E. R. Johnson, \& D. G. Taylor. 2009. The growth patterns of carcass tissues within wholesale cuts in fattening steer. J. Ind. Trop. Anim. Agric. 34: 153-158.

Priyanto, R. \& E. R. Johnson. 2011. Muscle growth and distribution in fattening steer of different breed. Med. Pet. 34: 19-22.

Purchas, R. W., A. V. Fisher, M. A. Price, \& R. T. Berg. 2002. Relationships between beef carcass shape and muscle to bone ratio. Meat Sci. 61: 329-337.

Vieira, C., A. Cerdeno, E. Serrano, \& A. R. Mantecon. 2006. Adult steer for beef production: Breed effect on animal performance, retail yield and carcass quality. Czech J. Anim. Sci. 51: 467-474. 